\title{
Novas configurações do ofício artesanal no México: ser artesão-artista
}

\author{
VANESSA FREITAG
}

\section{Resumo}

O presente trabalho é parte de um projeto de pesquisa de caráter etnográfico que busca analisar o trabalho criativo de artesãos-artistas mexicanos. O objetivo é pensar sobre algumas novas configurações que vêm tomando o ofício artesanal nesse contexto e de modo mais específico sobre a inserção de artesãos no circuito da arte. Participações em

Palavras-chave: Arte, artesanato, artesãos-artistas concursos artesanais, feiras, exposições em galerias e museus são alguns desses novos cenários para difundir e reconhecer o trabalho dos artesãos-artistas. 


\title{
New settings of the Mexican artisanal trade: being an artisan and artist
}

VANESSA FREITAG

\begin{abstract}
This work is part of an ethnographic researching project that pursues to analyze the creative work of Mexican artisanartists. The aim is to think and to reflect about some settings acquired by the Mexican artisanal trade and even more specifically about the induction of some artisans to the coterie of art. Engaging in artisanal contests, fairs, gallery and museum exhibitions are indicatives of these new scenes that disseminate and recognize the artwork of these artisans.
\end{abstract}




\title{
Nuevas configuraciones del oficio artesanal en México: ser artesano-artista
}

\author{
VANESSA FREITAG
}

\section{Resumen}

El presente trabajo hace parte de un proyecto de investigación de carácter etnográfico que busca analizar el trabajo creativo de artesanos-artistas mexicanos. El objetivo es pensar sobre algunas nuevas configuraciones que vienen tomando el oficio artesanal en ese contexto y de modo más específico sobre la inserción de artesanos en el circuito del arte. Participaciones

Palabras clave: Arte, artesanía, artesanos-artistas en concursos artesanales, ferias, exposiciones en galerías y museos son algunos de eses nuevos escenarios para difundir y reconocer el trabajo de los artesanos-artistas. 


\section{Introdução}

No México, a produção artesanal é tão vasta e variada que abarca todas as regiões do país. Difícil é conceber um estado como o maior e o mais sofisticado produtor de artesanato, dado que em qualquer parte da República Mexicana podemos encontrar uma riqueza cultural que se deixa vislumbrar no trabalho de seus artistas e artesãos. Não é à toa que o turismo movimenta, até certo ponto, grandes remessas econômicas no país e com ele, se concentram nas mãos de poucos, uma ampla circulação de mercadorias artesanais. Esses objetos são elaborados com virtuosismo e capricho, cujos materiais e funções se singularizam de acordo com cada região. $\mathrm{O}$ que une essa pluralidade é a característica inconfundível do trabalho artesanal: seu caráter manual; o uso de matérias-primas que são abundantes e próprias de cada região; a carga simbólica, cultural e imaginária que se observa nos motivos e temas criados pelos artesãos de um contexto artesanal.

Neste país, tanto os artesãos como suas criações são considerados símbolos identitários e servem de pauta do dia nos discursos de políticos e gestores da cultura no país. Lamentavelmente, o prestígio desses artesãos não se vê refletido na esfera que mais importa: na sua condição de vida. Paradoxalmente, o artesão mexicano vive o conflito de dar continuidade a um legado cultural e identitário do país; e por outro, o de encontrar condições favoráveis para seguir criando, produzindo e vivendo do seu trabalho, sem para isso, remoer a angústia de não ter recursos suficientes para a compra de matéria-prima e para o sustento da família. É difícil ser autônomo, independente, criativo quando as necessidades vitais reclamam maior atenção.

Nesse contexto, uma das alternativas encontradas pelos artesãos éa criação de peças que possam ser exibidas em circuitos 
considerados inicialmente, exclusivos da arte. Museus e galerias figuram como alguns desses campos nos quais se insere o trabalho criativo dos artesãos e onde a categoria "arte popular" ou "artesanato de autor" começam a ganhar força. À primeira vista, parece difícil classificar esses objetos como "arte" propriamente dita. Tanto o nosso olhar sobre o que consideramos arte como sobre o que consideramos artesanato já está amplamente formado de acordo com as referências estéticas e artísticas ocidentais e mais especificamente, europeias. Nesse sentido, tais valores estéticos se legitimam ao ponto de se definirem como universais (MARTINS; SÉRVIO, 2012).

Os espaços de difusão e circulação dessas obras configuram novas formas de conceber o ofício artesanal mexicano: não se trata somente de fazer manualidades, de saber dominar uma técnica ou de fazer um objeto com a finalidade de divertir, de ser útil, de enfeitar ou servir como objetos para rituais religiosos. Mas agora e também, com a finalidade de ser um objeto estético sem que para isso, tenha uma "utilidade" evidente.

A base empírica deste artigo está fundamentada nas experiências que tive pesquisando o contexto artesanal de três famílias de artesãos de uma cidade mexicana entre 2009 e 2010, respectivamente. Atualmente, dou continuidade à pesquisa me centrando nos casos de artesãos que participam ativamente em concursos artesanais. No plano teórico, me interessa revisitar as contribuições de Martins e Sérvio (2012), Larry Shiner (2010), Richard Sennett (2009), Escobar (2007), Roger Bastide (2006), Howard Becker (1978; 2008), Victoria Novelo (1997), Mario de Andrade (1938) entre outros, na tentativa de construir um argumento que reconheça o trabalho de artesãos e artesãs como artístico.

\section{$O$ artesão e o artista: revisitando a problemática dos conceitos}

El artesano representa la condición específicamente humana del compromiso (SENNETT, 2009).

El arte no pudo nacer sin la colaboración de los individuos (ROGER BASTIDE, 2006).

Tanto artistas como artesãos compartem características em comum na realização de seu trabalho criativo: geralmente, têm experiências estéticas e artísticas durante a infância; desenvolvem habilidades técnicas e manuais; dominam as ferra- 
mentas e matérias-primas que utilizam para criar; necessitam se informar constantemente para difundir e comercializar seu trabalho; e finalmente, estão familiarizados com imagens e imaginários coletivos que costumam usar como referência para a criação de seus objetos.

Agora, a intenção dos trabalhos (obras de arte ou artesanato) e sua recepção (museus, galerias, colecionadores ou para uso cotidiano), são significativamente diferentes. O mesmo acontece com o processo de aprendizado do trabalho: no caso dos artistas (plásticos, visuais ou audiovisuais), a formação artística geralmente se dá em espaços educativos formais (universidades, escolas, ateliês, entre outros) muito embora, existam casos de artistas que são autodidatas e aperfeiçoam seu conhecimento técnico por meio do tempo e da experiência dedicada ao trabalho artístico.

No caso dos artesãos, o aprendizado do trabalho artesanal acontece no âmbito familiar e comunitário (com vizinhos ou parentes); eventualmente, esse aprendizado inicial se dá quando são ajudantes de outros artesãos. Aprende-se a ser artesão fazendo artesanato, não há outra forma. Em outras palavras, o trabalho artesanal é parte da tradição e da cultura de uma comunidade, portanto, não se aprende no âmbito universitário e muito menos nas escolas formais, embora até existam escolas que ensinem as bases técnicas de certos ofícios, como pude observar no contexto artesanal mexicano. Finalmente, Becker (2008) sustenta que os artistas e artesãos se parecem em um aspecto: pertencem a uma comunidade bem organizada e produzem seu trabalho como parte da mesma.

As semelhanças entre artesãos e artistas se visualizam em dois aspectos: o aprendizado manual e o intelectual de suas criações, onde até certo ponto, realizam uma atividade de cunho estético e criativo. Muitas obras de arte com linguagens contemporâneas (objeto-arte, performances, instalações, etc.) ainda conservam características manuais em sua confecção. No caso do artesanato, pode estar constituído de elementos que superam a ideia de objeto utilitário, decorativo e adquirir um status de artístico (BECKER, 2008). No entanto, com relação ao papel que desempenha a estética na arte e no artesanato, podemos mencionar que na primeira, requer a supremacia exclusiva da função estética, enquanto que na arte popular, essa função geralmente se confunde com outras (sociais, religiosas, etc.). Por isso, as criações folclóricas não chegam a ser artísticas: na arte popular, a forma estética não é autônoma e também não se impõe sobre outras configurações culturais (ESCOBAR, 2007). 
A circulação e comercialização de seus objetos também obedecem a uma lógica própria, embora em ambos os casos, ter uma peça exposta num museu ou galeria possa significar algumas conquistas para o artesão, tais como o reconhecimento e diferenciação entre os demais artistas e artesãos que são seus contemporâneos. Ao mesmo tempo, o espaço contribui no processo de legitimação da arte popular. A respeito disso é interessante abordar as contribuições de Ramos (2010) sobre o caso da gravura popular brasileira. O autor argumenta que a legitimação da arte popular é um processo fundamental para determinar sua própria existência, ou seja, a arte popular só existe quando passa a ser reconhecida por instâncias oficiais.

A arte popular, outro grande tema frequentemente esquecido pela História da Arte, que só existe realmente, como categoria artística, a partir do momento em que passa por um processo de legitimação. E, sempre, de legitimação por instâncias oficiais, externas ao universo onde as obras são originalmente produzidas e consumidas (RAMOS, 2010, p.41).

No caso da gravura popular brasileira, o autor analisa como esta deixa de ser vista como um objeto qualquer vendido em feiras e mercados, e passa a ser reconhecida como um objeto artístico quando exposta em museus e galerias. Os meios de comunicação e de difusão (tais como artigos na imprensa, exposições, publicação de álbuns, livros, entre outros), contribuem para identificar a gravura como obra artística, assim como, a vigência de um discurso folclorista que exalta as especificidades sociais e culturais de terminados objetos criados pelo "povo". De acordo com Martins e Sérvio (2012), os meios de comunicação (incluindo o ciberespaço) são potencializadores de imagens e discursos construídos sobre as diferentes matrizes culturais. Só a partir do momento em que o artesão tem seu trabalho exposto e difundido em espaços legitimadores é que este também começa a se reconhecer como artista e a conceber seu trabalho como arte - no sentido moderno do termo-, (RAMOS, 2010). No contexto mexicano, os artesãos chegam a reconhecer o que produzem como arte quando querem se referir à sua habilidade manual e outras vezes, à sua capacidade inventiva (FREITAG, 2014).

Abordar as diferenças e similitudes entre a arte e o artesanato é adentrar-se num campo sinuoso e em fronteiras pouco precisas. Escobar (2007) adverte que se faz necessário construir uma teoria da arte popular dado que atualmente, a 
discussão sobre os conceitos de arte, artesanato ou de cultura popular são cada vez mais abundantes e problematizados desde diferentes disciplinas teóricas: encontramos aportações da história e crítica de arte, da filosofia, dos estudos culturais, da teoria estética, da antropologia e da sociologia. Como exemplo, no campo da sociologia e da antropologia, podemos mencionar as contribuições de Good (2010), Bourdieu (2010), Belting (2007), Bastide (2006), Gell (1998), Becker (1982) quando discutem o papel social da arte e do artista e também do artesão e do artesanato na sociedade ocidental.

Como bem sabemos, tanto o conceito de arte como o de artista foi construído desde a perspectiva ocidentalizada da cultura e com ele, a concepção de "genialidade" e "individualismo" para conceber a criação de uma obra de arte. Como parte dessa ideia ocidentalizada da arte, Good (2010) faz uma importante reflexão:

(...) existe uma imagem do artista que, desde o romantismo, se desdobra como um indivíduo especialmente imaginativo e criativo, dotado de uma visão e um talento fora do comum, que produz obras de modo solitário em momentos de grande inspiração. (...) A autoria individual de obras originais é uma das características nas definições convencionais da arte (GOOD, 2010, p.47, tradução livre da autora).

Neste sentido, especialmente no contexto latino-americano, a categoria "arte" se refere à produção ocidental importada durante a colonização, mesma que adquire características regionais fundamentalmente vinculadas às políticas culturais dos setores hegemônicos. Ao mesmo tempo, foram os responsáveis pela criação de Academias de Arte, Museus, Salões e Coleções de arte, e que legitimaram os cânones artísticos europeus (BOVISIO, 2002).

Por outro lado, a palavra artesanato se origina do latim vulgar artitianus e se refere ao trabalhador que é hábil numa determinada atividade (PÉREZ MARTÍNEZ, 2010). Este autor assume $\mathrm{o}$ artesanato como um dos mais profundos e eficazes sistemas de comunicação considerados como mecanismo de transmissão ancestral e de saberes que são ensinados e aprendidos num contexto familiar. O artesanato expressa o que compreendemos como cultura, e estes são elementos importantes na constituição da identidade e dos conteúdos da mesma: expressão da espiritualidade, das crenças, dos rituais e dos sistemas simbólicos de uma determinada sociedade. Bovisio (2002) 
menciona que entre os especialistas, as discussões sobre o uso das categorias "arte popular" e "artesanato" evidenciam contradições instauradas desde seu nascimento, especialmente, no contexto da consolidação do campo autônomo das artes plásticas. Atualmente, artesanato e arte popular carregam consigo, significados distintos:

Artesanatos são aqueles objetos que buscam satisfazer uma necessidade material, mas que carregam consigo elementos formais cujo propósito é embelezá-los para satisfazer uma necessidade espiritual. Arte popular definiria as obras que não abarcam nenhuma necessidade material e somente objetivam dar gozo estético, ou seja, o de nos comunicar um universo simbólico (BOVISIO, 2002, p.51, tradução livre da autora).

Em vista do anterior, podemos observar que no discurso sobre os objetos artesanais já se começa a reconhecê-los como expressão de valores estéticos, frutos da criatividade e originalidade do artista popular, e que este, ao mesmo tempo, incorpora a possibilidade de recriar e reelaborar de maneira individual ou regional, os legados de sua tradição.

No entanto, nem todas as coisas que hoje em dia se consideram como arte foram criadas com esta intenção, e nem tudo o que se considera artesanato foi visto sempre como uma "arte menor". Tanto a arte como o artesanato têm uma história em comum, onde se evidencia uma recente separação entre ambas as linguagens (se levarmos em consideração a antiguidade dessas disciplinas). Para poder entender um pouco mais a relação entre arte e artesanato, entre artesão e artista, e de como entendo o conceito de artesão-artista é importante revisitar alguns autores.

No livro de Larry Shiner (2010), o autor propõe entender como e quando o antigo sistema arte/artesanato (complexo e integrado) foi sendo substituído por um novo sistema que distinguia radicalmente as belas artes do artesanato. $\mathrm{O}$ autor defende a ideia de que os antigos gregos careciam de uma categoria de arte e, portanto, também não tinham uma palavra para nominá-la. Neste sentido, techné é a palavra que com frequência traduzimos por arte ou também ars (romana), no entanto, ambas as palavras significavam muitas coisas que hoje em dia denominamos como "ofícios".

Assim sendo, techné/ars podiam ser interpretadas como a capacidade ou a destreza humana para elaborar/criar coisas e objetos, como também para executá-los. A antiga ideia do artista 
estava muito mais próxima à nossa atual ideia de "homem de ofícios", dado que o artesão/artista grego "tinha que combinar uma capacidade intelectual para captar princípios com um entendimento prático, com certa destreza e graça" (SHINER, 2010, p.5o). Se retrocedermos no tempo e nos detivermos nas manifestações artísticas pré-históricas, a arte tinha pouca relação com a concepção de beleza, muito menos com contemplação estética.

Ainda na sociedade primitiva, a arte era um instrumento mágico, uma arma da coletividade humana na luta pela sobrevivência (FISCHER, 1983). Portanto, não se tratava de uma produção individual, mas coletiva, ou seja, uma atividade social por excelência. Da mesma forma, argumenta o sociólogo da arte Roger Bastide (2006), quando discute a origem social e coletiva da arte, definindo-a como uma atividade técnica do homem. Para ambos os autores, a arte estava diretamente relacionada com a prática de rituais ou para proteger o corpo (como os adornos corporais), respondendo assim, a fins utilitários e também à satisfação de necessidades coletivas e religiosas. $\mathrm{O}$ conceito de arte tal e como conhecemos atualmente foi uma invenção da modernidade, mais especificamente a partir do Renascimento.

No Renascimento, a beleza se impôs como finalidade nas artes plásticas e se tornou o principal propósito das pesquisas realizadas pelos artistas. Esse fato marca a separação entre o trabalho do artesão e o do artista. Com esta separação, as atividades imaginativas foram vinculadas ao trabalho do artista, enquanto que aquelas relacionadas com a confecção de objetos se relacionaram exclusivamente ao do artesão:

(...) todos os aspectos nobres da antiga imagem do artesão/ artista, tais como a graça, a invenção, a imaginação, ficaram adscritos unicamente ao artista enquanto que o artesão se caracterizou exclusivamente como aquele que possui certa destreza ou habilidade para trabalhar de acordo às regras, retratando-o como um indivíduo que só se interessava pelo dinheiro (SHINER 2010, p.34, tradução livre da autora).

No entanto, Bastide (2006) nos recorda que o artista foi primeiramente um escravo ou um artesão que não era mais bem pago que os artesãos de outros ofícios; não podia, pois, melhorar sua condição social além das oferecidas por um abastado mecenas. No Renascimento, se forja o conceito de que a elaboração de um trabalho artístico exigia um talento especial do artista, um dom ou uma grande habilidade para 
expressar, por meio das formas e cores, objetos belos, sem um fim utilitário mais do que o de provocar prazer estético. Gradualmente, se gesta o mito do artista cujo trabalho se caracteriza como algo com valor diferencial:

(...) o status de qualquer atividade em particular, como uma atividade fundamental que requer dos dotes do artista ou como simples apoio, pode mudar. Como podemos ver, as pinturas que alguma vez foram pensadas como um trabalho especializado, mas não mais que isso, se definiu como algo especial no Renascimento (BECKER, 1982, p.17, tradução livre da autora).

Finalmente, as noções de talento, dom e beleza foram predominantes para definir a um artista. Por outro lado, a habilidade técnica e manual foi revista e algumas vezes evitada em muitas das produções artísticas desde a arte moderna, especialmente a partir de Duchamp, da arte conceitual e muitas das obras de arte contemporânea (MICHAUD, 2007). Não se pretende aqui, reivindicar o artesanal nas obras de arte atuais, e sim, tratar de aproximar-nos a uma reflexão sobre como surge a dissociação entre o trabalho manual e mental, belo e utilitário, artístico e artesanal.

No livro de Richard Sennett (2009), o autor buscou explorar o que acontece quando, na prática do trabalho artesanal, se dissociam a mão da mente, a ciência da técnica, a arte do ofício, para num segundo momento, problematizar criticamente a concepção do artesanato como uma prática exclusivamente manual. Para o autor, todo artesanato se fundamenta numa habilidade desenvolvida em alto grau e que o artesão representa o compromisso de fazer bem os objetos que produz. Sobre isto, Becker (2008) acrescenta que a diferenciação entre artes e ofícios é feita pelos membros do mundo da arte quando reconhecem que para fazer arte, os artistas necessitam ter alguma habilidade manual (técnicas) que poderiam se considerar artesanais.

No entanto, insistem em que os artistas, a diferença dos artesãos, aportam ao produto criado algo que nasce das habilidades e dotes criativos. Mas e os artesãos, não são por acaso, capazes de criar trabalhos inventivos e transcendentes? Parece-me bastante cômodo identificar os artífices como aqueles que são exclusivamente hábeis com as mãos. Nesse sentido, considero que além das capacidades técnicas e o domínio sobre a matéria, os artesãos também são exímios criadores, cujo trabalho pode nos provocar uma série de experiências estéticas. 
Diz Sennett (2009, p.33) que ao criar um novo objeto, o artesão sente recompensa emocional; seu trabalho se fundamenta numa realidade tangível e pode se sentir orgulhoso do que faz. E complementa dizendo que no passado, a sociedade conseguiu bloquear essas recompensas e continua bloqueando atualmente, sobretudo quando a atividade prática e a habilidade técnica passam a ser relegadas e desvalorizadas, enquanto que as intelectuais/conceituais passam a ser prestigiadas. São esses aspectos importantes para entender o contexto de artesãos-artistas mexicanos. Sobre este ponto, gostaria de discutir a próxima parte do artigo.

\section{Sobre como ressignificar o artesanato e o trabalho do artesão: uma experiência em Guadalajara, México}

Os modos de apreciação do trabalho artístico e artesanal, assim como, dos objetos criados pelos artesãos e artistas são, antes que nada, formas culturais de ver: "geralmente, a sociedade ocidental denomina como artesãos pela sua maneira de trabalhar, embora entre eles existam verdadeiros artistas criadores que talvez não se ajustem aos cânones da academia, nem nos seus modos de conceber o aprendizado, nem nos seus modelos" (NOVELO, 2002, p.171, tradução livre da autora). Ainda de acordo com a autora, esse modo de ver o trabalho artesanal como não artístico tem muito a ver com as desigualdades geradas pelo baixo reconhecimento social e econômico da atividade artesanal. Em referência ao anteriormente exposto, vale a pena refletir sobre a seguinte citação:

Os códigos europeus e o código branco norte-americano são os únicos válidos. Instituições, historiadores da arte, curadores e artistas em geral não têm a preocupação pelo pluralismo cultural, a multiculturalidade, o interculturalismo, etc. E quando tem é em nome do folclore, e o folclore já é uma designação colonialista. A palavra e o conceito foram criados pelos ingleses para designar as manifestações artísticas e culturais dos povos colonizados que não seguiam o padrão dominante da cultura inglesa. Folclore para os ingleses é a "arte" do outro (BARBOSA, 2009, s/n).

A arte, como parte das manifestações culturais de um povo ou nação, está atravessada por ideologias que dominam os modos de vê-la e de concebê-la sobre outros possíveis. No 
contexto artesanal mexicano, os artesãos-artistas obtêm reconhecimento social quando aparecem com frequência nos jornais locais, viajam para participar de feiras, participam de exposições artesanais, e quando sua imagem é usada pelo governo local para promover o turismo da cidade. Quando o artesanato se incorpora ao mercado, se desenvolve de tal maneira que passa a ser visto exclusivamente como objeto decorativo "totalmente despojado de toda função utilitária, religiosa ou de prestígio social” (BOVISIO; 2002, p. 35, tradução livre da autora). No entanto, mesmo com certo prestígio, grande parte desses artesãos ainda vive em condições de pobreza extrema e de carência de recursos econômicos:

(...) a separação que se faz entre os produtores e suas obras no campo da admiração tem, também, um ingrediente de discriminação cultural no campo da apreciação estética, pois ao mesmo tempo em que se valoriza uma das expressões culturais de uma sociedade, não se permite o acesso a uma melhor qualidade de vida (NOVELO, 2002, p.173, tradução livre da autora).

Ao se interessar pelo trabalho artístico desde um enfoque sociológico, Howard Becker (2008) analisa as condições que possibilita a realização de uma obra de arte. Para o autor, o trabalho artístico, como toda atividade humana, depende da colaboração e do trabalho conjunto de uma série de pessoas. $\mathrm{E}$ as formas de cooperação (efêmeras ou rotineiras) é o que caracteriza os mundos da arte: "os mundos da arte consistem em todas as pessoas cuja atividade é necessária para a produção dos trabalhos característicos que esse mundo, e talvez também outros, definem como arte" (BECKER, 2008, p. 54). Nesse sentido, Becker também se interessa pelo trabalho daqueles que considera que estão à margem dos mundos da arte, tais como, os artesãos. Por tanto, distingue as atividades realizadas pelos artistas das criadas pelos artistas-artesãos e ao mesmo tempo, daquelas elaboradas pelos artesãos.

Neste estudo, denomino "artesão-artista" como aquela pessoa que cria objetos manuais que são exclusivos e únicos, com virtuosismo e sentido estético; na maioria das vezes, considera o que faz como arte, e com relativa frequência, participa de exposições artesanais produzindo e comercializando seus objetos para colecionadores de arte. Alguns artesãos "se referem a si mesmos não somente como artesãos, mas também como artistas" (Becker, 1978, p.166, tradução livre da autora). No caso dos artesãos em México, se bem costumam se refe- 
rir ao seu trabalho como uma arte e o que fazem como arte, nem sempre se identificam como artistas, mas simplesmente, como artesãos que fazem arte.

Dado o interesse de estudar artesãos mexicanos que viviam e trabalhavam como tal no contexto urbano, achei conveniente realizar este estudo numa localidade próxima à cidade de Guadalajara. Minha primeira visita à Tonalá (cidade que forma parte da zona metropolitana de Guadalajara, com aproximadamente 500 mil habitantes) me impactou positivamente. Durante minha estância nessa localidade, aprendi a reconhecer diferentes tipos de artesanato e de artesãos, tais como: a) artesãos tradicionais, cujos processos artesanais foram herdados de geração em geração; b) artesãos que "maquilan", ou seja, compram peças previamente produzidas por outros artesãos e se dedicam exclusivamente a comercializá-las; c) artesãos que produzem objetos utilitários e comerciais (manualidades); d) artesãos considerados artistas, que elaboram peças exclusivas, participam de concursos e inovam constantemente (sobre este último, me interessa dedicar algumas linhas).

É importante ressaltar que o artesanato que se produz em Tonalá não é um caso isolado quando se pensa em México: de norte a sul do país podemos encontrar artesãos genuínos, verdadeiros "representantes" da cultura nacional e originários de contextos urbanos, assim como, de comunidades indígenas. $\mathrm{O}$ artesanato fomenta o turismo e a vinda de estrangeiros de todas as partes do mundo, mas especialmente, dos Estados Unidos e Europa. Atualmente, os artesãos mexicanos se enfrentam com o competitivo mercado do artesanato de procedência asiática (chinês), sendo os principais concorrentes e os que mais copiam e reproduzem as peças criadas por tradicionais artífices. Este é um problema que se agrava com o passar dos anos e os artesãos não têm orientação profissional sobre como proteger seu trabalho da pirataria asiática.

No entanto, uma alternativa que encontram para se defender, de alguma forma, dessa desleal competição é a invenção de novas linhas artesanais, imprimindo identidade e estilo próprio em cada peça criada. Se tem algo que o mercado asiático não pode copiar e reproduzir é o conhecimento técnico e o refinado sentido estético desses criadores. Nesse sentido, Novelo (1997) define o artesanato mexicano como obras plásticas, produtos de um processo de trabalho particular onde o produtor combina seus conhecimentos das matérias-primas com o design, cujas habilidades e destrezas, criarão objetos manuais providos de elementos estéticos e conceituais. 
Estando em Tonalá, conheci a uma família tradicional de artesãos (Família Jimón) com uma produção artesanal muito diversificada: eram premiados em concursos artesanais e inovavam constantemente suas peças artesanais. Os integrantes colecionavam certificados de prêmios e participações em concursos e exposições em museus. Vendiam suas peças de coleção num valor muito superior se comparado com a maioria dos artesãos que se dedicavam à comercialização de linhas decorativas ou utilitárias. Com frequência, eram convidados a dar entrevistas nos meios de comunicação como jornais e televisão. Viajavam a muitos estados da República Mexicana e inclusive, para o estrangeiro (especialmente, para os Estados Unidos). Gostavam de arte e se consideravam artistas, mas também artesãos. Esta família não era um caso isolado no contexto artesanal tonalteca, onde pude observar que o artesão-artista era um tipo de artesão muito apreciado no povoado, surgido dos concursos artesanais que se realizavam anualmente nessa localidade.

Para que um artesão participe de um concurso, precisa apresentar um trabalho novo, original e que vincule técnicas tradicionais com uma visão moderna, exclusiva. Pode levar meses trabalhando num único projeto porque o conceito que se visualiza nesses concursos não é, necessariamente, o resgate de tradições culturais e populares, mas o de fomentar a criatividade e a competitividade entre os artesãos tonaltecas.

De acordo com esses artesãos, ao mesmo tempo em que aprenderam a valorizar os objetos que criavam, também reconheceram a necessidade de pensar num espaço especialmente dedicado à exibição desses. A iniciativa se deu depois de participarem de muitos concursos artesanais e observarem o modo como os objetos eram expostos nos museus. Este caso é um exemplo que melhor expressa as características do artesão-artista: num primeiro momento, desestabiliza a ideia preconcebida de que artesãos não sabem agenciar seus objetos, de que permanecem passivos esperando a chegada dos compradores; se diversificam ao ponto de expor em museus e galerias; elaboram peças sofisticadas pensando num tipo específico de comprador: os colecionadores de arte ou o público interessado por um objeto artesanal exclusivo e único. Por meio do trabalho artesanal, esses artesãos criam objetos tanto de caráter decorativo, utilitário e também artístico, condensando aspectos econômicos, sociais e culturais que expressam a visão de mundo de povos indígenas e mestiços. 

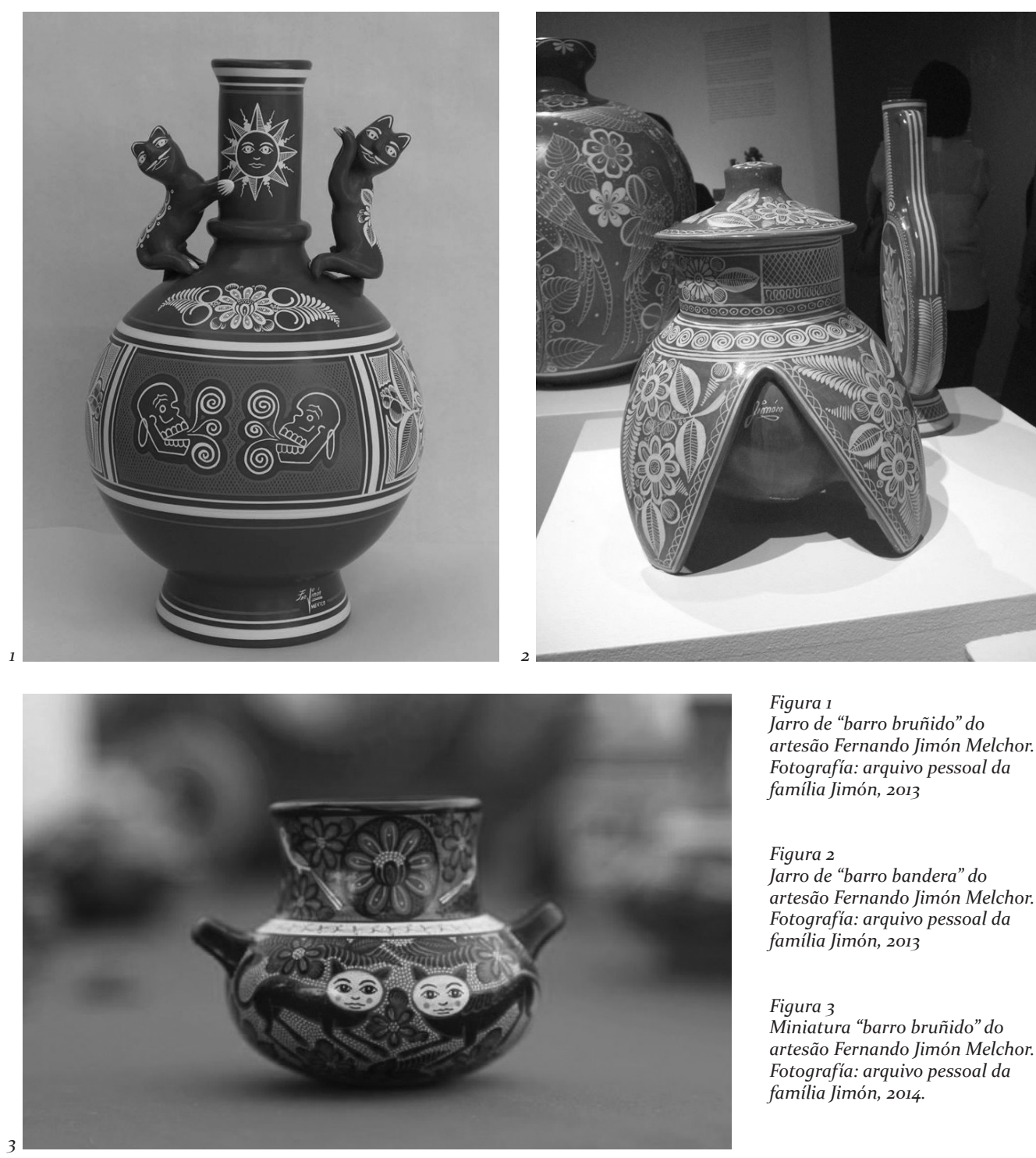

Figura 1

Jarro de "barro bruñido" do artesão Fernando Jimón Melchor. Fotografía: arquivo pessoal da família Jimón, 2013

Figura 2

Jarro de "barro bandera" do artesão Fernando Jimón Melchor. Fotografía: arquivo pessoal da família Jimón, 2013

Figura 3

Miniatura "barro bruñido" do artesão Fernando Jimón Melchor. Fotografía: arquivo pessoal da família Jimón, 2014.

As imagens anteriores expressam algumas das principais técnicas e estilos criados por artesãos e artistas populares de Tonalá (Guadalajara). À primeira vista, essas peças evidenciam o fino sentido estético desses artesãos, cujo refinamento se forja pela constância no ofício e o gosto pelo bem feito (BECKER, 2008). Um trabalho bem acabado é tão ou mais importante quanto à variedade ou à criatividade das linhas 
artesanais. O que esses artesãos consideram como bonito do trabalho que realizam é saber que este será elaborado com perfeição e virtuosismo e que ao mesmo tempo, conquistará o gosto dos possíveis consumidores.

Os respectivos trabalhos foram recentemente expostos em um Museu de Arte Popular da cidade de Tonalá, Jalisco, e gentilmente cedidos por uma das famílias pesquisadas entre 2009 e 2010. Uma peça exposta num museu adquire um valor muito superior àquelas que não tiveram o mesmo destino. Portanto, os museus não só se caracterizam como espaços que continuam legitimando o trabalho artístico em si mesmo, mas também o artesanal. Isto repercute diretamente no valor agregado dessas peças que, embora continuem sendo vistas como artesanato ou arte popular (e não como "arte"), chegam a ser comercializadas para colecionadores expertos no tema.

Não é por acaso que os artesãos-artistas, ao participarem destes eventos, desenvolvem um tipo de trabalho com conotações mais artísticas que artesanais. Um exemplo disso são aquelas peças que levam a assinatura do artesão como forma de comprovar a autenticidade do objeto criado. A assinatura transforma o sentido das obras dado que estas deixam de ser lidas em estreita vinculação com a natureza e a vida social, e passam a ser vistas em relação com as outras obras do autor, individualizando o trabalho do artesão (BOVISIO, 2002).

\section{Considerações finais}

Neste artigo, propus repensar os modos de conceber o ofício artesanal tomando como estudo de caso, o contexto artesanal mexicano. Repensar as formas de ver implica desacomodar nossos juízos e pré-concepções sobre as coisas e os fenômenos. Implica, inicialmente, entender o modo como vemos e ao mesmo tempo, compreender por que vemos dessa forma. Trata-se de um exercício constante dado que desconstruir imagens e conceitos arraigados sobre a realidade nos toma mais tempo e esforço que construí-los.

Neste sentido, seria um exercício interessante se pudéssemos começar a ver e a pensar algumas criações populares como arte. No entanto, esse exercício também nos exigirá algumas precisões a fim de poder reconhecer e nomear os objetos artesanais que são pensados com a finalidade de ser arte ou que são assim considerados quando comercializados em galerias e museus. Para isso, é importante salientar que Escobar (2008) nos diz que nem tudo aquilo que se conside- 
ra "cultural" é "artístico", assim como, nem todas as culturas populares geram formas artísticas. Alguns tipos de artesanato continuarão sendo criados exclusivamente para este fim: este é o caso das culturas indígenas que utilizam objetos artesanais estreitamente vinculados com rituais ou costumes da comunidade (Escobar, 2008).

Ainda assim, entre as possíveis configurações que vêm adquirindo o ofício artesanal poderia mencionar a identificação do artesanato como objeto artístico e sua inserção em espaços inicialmente destinados às artes. Considero também, que há muitos artistas entre os artesãos mexicanos, ou seja, artistas-artesãos que identificam e comercializam seus trabalhos como arte. Penso que o trabalho realizado pelos artesãos é arte tanto no sentido tradicional do termo, ou seja, como uma habilidade ou destreza para fazer algo bem feito, onde mão e pensamento não estão dissociados; como no sentido moderno, quero dizer, como um objeto estético desvinculado de uma função ou uso na vida cotidiana.

Em nossa sociedade, ou seja, a sociedade de artesãos, a de artistas, a de consumidores de arte ou de artesanato, já não consegue ver e nem considerar o trabalho de artesãos como arte (especialmente, certos tipos de artesanato que se destacam pelo seu caráter artístico) porque a excisão entre ambas as linguagens está fortemente assentada na literatura sobre $o$ tema e na vida cotidiana de artistas e artesãos. As diferenças residem nos espaços de circulação dos objetos artísticos se comparado com os artesanais, no valor outorgado ao objeto e ao produtor, na visibilidade que se confere às respectivas produções e na valorização social, que evidencia as polaridades entre arte e artesanato. A oposição que se observa não é ideologicamente neutra.

Finalmente, penso que é necessário fomentar novos olhares e debates que problematizem a situação do trabalho artístico artesanal na atualidade, tanto no contexto acadêmico como no escolar. Sem dúvida, se observam mudanças importantes relacionadas com o fazer artesanal que requerem de um olhar mais inclusivo. Entre essas mudanças, mencionaria o processo criativo de artesãos que em muito se aproxima ao processo criativo dos artistas (um âmbito a ser pesquisado seriamente), sem contar que muitos objetos artesanais possuem uma força que impugna sua presença como arte. Outro panorama de estudo que se abre é a necessidade de pesquisas que se centrem em analisar casos de artesãos (e também de artistas), cujas produções dialoguem ao ponto de romper com 
suas fronteiras disciplinares. Por último, espera-se que ao reconsiderar formas de olhar e conceber os objetos e seus criadores, também se possa reverter em atitudes que realmente valorizem o trabalho dos nossos artesãos-artistas.

\section{Referências}

ANDRADE, Mario (1938). O artista e o artesão. Disponível em: <http://www.eba.ufmg.br/alunos/kurtnavigator/arteartesanato/filos-03-artesao.html>.

BARBOSA, Ana Mae. Arte y Cultura. Encuentro Nacional sobre Arte y Diversidad Cultural. Perú, o5 al o7 de noviembre de 2009. Disponível em:< http://encuentroeducacionarte. blogspot.mx>.

BASTIDE, Roger. Arte y Sociedad. México: Fondo de Cultura Económica, 2006.

BECKER, Howard. Los mundos del arte. Sociología del trabajo artístico. Bernal: Universidad Nacional de Quilmes Editorial, 2008.

. Arts and Crafts. American Journal of Sociology, v. 83, n. 4 jan., 1978, p. 862-889.

BELTING, Hans. Antropología de la imagen. España: Katz Editores, 2007.

BOVISIO, María Alba. Algo más sobre una vieja cuestión: arte vs artesanías. Buenos Aires: FIAAR, 2002.

BOURDIEU, Pierre. El sentido social del gusto. Elementos para una sociología de la cultura. Siglo Veintiuno Editores: Buenos Aires, 2010.

ESCOBAR, Ticio. El mito del arte y el mito del Pueblo. Cuestiones sobre arte popular. Asunción: RP Ediciones/Museo del Barro, , 2008.

FISCHER, Ernst. A necessidade da arte. São Paulo: Editora Cortez,, 1983.

FREITAG, Vanessa. "Entre arte e artesanías: elementos para pensar el oficio artesanal en la actualidad". In: El Artista, nro.11, diciembre, 2014, p.129-143, Colombia.

GELL, Alfred. Art and argency. An Anthropological theory. Clarendon Press, Oxford, 1998.

GOOD, Catherine. La antropología del arte en México. In: ARAIZA HERNÁNDEZ, Elizabeth, (Ed.), Las artes del ritual. Nuevas propuestas para la antropología del arte desde el occidente de México. Zamora: El Colegio de Michoacán, Zamora, 2010.

MARTINS, Raimundo; SÉRVIO, Pablo Passos. Polêmicas e indagações acerca das classificações da cultura: alta, baixa, 
folk, massa. In: Visualidades, Goiânia, Brasil, v.1o.n.1, jan-jun, pp.129-149, 2012.

MICHAUD, Yves. El arte en estado gaseoso. Ensayo sobre el triunfo de la estética. México: Fondo de Cultura Económica, 2007.

NOVELO, Victoria. . Ser indio, artista y artesano en México. In: Espiral, n. 25, v. 9, Universidad de Guadalajara, Guadalajara, pp.165-178, 2002.

Las artesanías mexicanas. En: FLORESCANO, E.

(Coord.). El patrimonio nacional de México, II. México: Fondo de Cultura Económica, 1997. p.111-129.

PÉREZ MARTÍNEZ, Herón. El sentido de las artesanías en el concierto de la cultura. In: XXXII Coloquio de antropología e Historia Regionales, Zamora, México, 2010.

RAMOS, Everardo. Do mercado ao museu: a legitimação artística da gravura popular. In: Visualidades, v.8, n.1, Goiânia, Brasil, p.39-57, 2010.

SENNETT, Richard. El artesano. Barcelona: Editorial Anagrama, 2009.

SHINER, Larry. La invención del arte. Una historia cultural. Paidós: Barcelona-Buenos Aires-México, 2010.

Recebido em: 04/03/15

Aceito em: 31/03/15

\section{VANESSA FREITAG}

vanessa.freitag@gmail.com

Professora pesquisadora da Universidad de Guanajuato, Câmpus León. Departamento de Estudos culturais. Doutora em Ciências Sociais com ênfase em Antropologia Social (CIESAS-Occidente, Guadalajara). 